\title{
Synthesis and characterization of new homologous series of unsymmetrical liquid crystalline compounds based on chalcones and 3, 5-disubstituted isoxazoles
}

\author{
SOWMYA P T and K M LOKANATHA RAI* \\ Department of Studies in Chemistry, University of Mysore, Manasagangothri, Mysuru, Karnataka, India \\ Email: ptsowmya8@gmail.com; kmlrai@yahoo.com
}

MS received 24 August 2016; revised 28 October 2016; accepted 7 November 2016

\begin{abstract}
Two homologous series of unsymmetrical alkylated chalcones and 3,5-diaryl isoxazoles, consisting of 20 members, with various n-alkyl bromides $(n=2-7,10,12,14,16)$ have been synthesized and studied for their liquid crystalline property. Simple strategy was employed to achieve the target materials. Flexibility in the synthesized molecules is provided by attaching straight alkoxy chains, where one terminal group is fixed and other terminal group is varied. The synthesized compounds were characterized on the basis of Mass, IR and NMR spectroscopy. The stability and the range of the mesophases increased with the length of the chain on the isoxazoles. The melting point, transition temperatures and enantiotropic liquid crystal morphologies were determined by polarizing optical microscopy (POM) in conjunction with a hot stage and by differential scanning calorimetry (DSC).
\end{abstract}

Keywords. Anisotropy; chalcones; isoxazoles; enantiotropy; nematic; smectic.

\section{Introduction}

Some substances exhibit an intermediate state of matter with molecular ordering in between that of the conventional crystalline solid and isotropic liquid phases, and this state of matter is called a liquid crystal (LC) state or mesomorphic state, which is an anisotropic liquid. Liquid crystalline materials are useful in electronic devices (LCDs), medical thermographic instruments, photoconductors and semiconductor materials, pharmaceutical preparations and the textile industry. ${ }^{1}$ The prime requirement to induce liquid crystalline properties in a substance are molecular rigidity and flexibility. ${ }^{2-5} \mathrm{Mo}-$ lecular rigidity and flexibility occur as a consequence of the molecular shape, size and types of the central, terminal and lateral groups and their polarities, molecular polarity and polarizability, etc. During the past decades, a large number of liquid crystalline compounds containing heterocyclic units such as isoxazole,${ }^{6-9}$ pyrazole, ${ }^{10}$ thiadiazole, imidazole and oxadiazole ${ }^{11-13}$ units have been synthesized. Several methods have been employed for the synthesis of unsymmetrical 3,5-disubstituted isoxazoles, including 1,3-Dipolar Cycloaddition reaction, ${ }^{14}$ and condensation of 1,3-dicarbonyl compounds with hydroxylamine and condensations. ${ }^{15}$ Our interest in synthesizing isoxazole derivatives comes from the ease of synthesis and their excellent mesomorphic behaviour. The isoxazole ring incorporates a strong

\footnotetext{
*For correspondence
}

dipole moment which helps to increase the anisotropy of polarizability and consequently favour mesogenic behaviour. ${ }^{16}$ The attainment of mesogenic isoxazoles through the use of $\alpha, \beta$-unsaturated ketones forms an easy way to prepare molecular structures for the synthesis of non-polymer enantiotropic liquid crystalline materials. Research work on $\alpha, \beta$-unsaturated ketone based liquid crystals has been extensively carried out in order to study the relationships between structure and mesomorphic properties. ${ }^{17}$ In this work, we have synthesized $\alpha, \beta$-unsaturated ketones (intermediates, Series I) and their isoxazoles derivatives (Series II) in order to study their liquid crystalline properties.

\section{Experimental}

\subsection{General procedure for the synthesis of 1-(4-(octyloxy)phenyl)ethanone and alkylated benzaldehyde (1 and $\mathbf{2}$ )}

A mixture of p-hydroxy acetophenone (1 mmol), octylbromide ( $1 \mathrm{mmol}$ ) and $\mathrm{K}_{2} \mathrm{CO}_{3}(3 \mathrm{mmol})$ in $\mathrm{N}, \mathrm{N}$-dimethyl formamide $(25 \mathrm{~mL})$ was stirred at room temperature for $4 \mathrm{~h}$. The reaction was monitored by TLC. After the completion of reaction, the product was extracted into ether layer and it was dried over anhydrous $\mathrm{Na}_{2} \mathrm{SO}_{4}$ to obtain 1-(4-(octyloxy)phenyl)ethanone (1). Similarly the above procedure was followed to obtain 4alkylated-3-methoxybenzaldehyde (2) with different n-alkyl halides from 4-hydroxy-3 methoxybenzaldehyde. 
2.2 General procedure for the synthesis of 3-(4-alkoxy3-methoxyphenyl)-1-(4 octyloxy)phenyl)prop-2-en-1-one $(3 a-3 j)$

The most common procedure to synthesize $\alpha, \beta$-unsaturated ketones is the classic Claisen-Schimdt reaction by a well established method. ${ }^{18}$ Synthesis involves the condensation of alkylated aromatic aldehyde (1 mmol) with 1-4-(octyloxy) phenylethanone $(0.6 \mathrm{mmol})$ in ethanol and the reaction mixture was maintained in a cold water bath. $10 \mathrm{~mL}$ of $10 \%$ $\mathrm{NaOH}$ solution was added dropwise and the reaction mixture was stirred for $5 \mathrm{~h}$ at $40-50^{\circ} \mathrm{C}$. After cooling, the crude product was filtered under suction and extracted into ether layer and concentrated to obtain pale yellow solid, which was further purified by repeated recrystallization from ethanol to get the unsymmetrical $O$-alkylated chalcones of $\mathbf{3 a}-\mathbf{3 j}$ series. In this scheme, all the compounds were obtained in good yields. The synthetic pathway to the target compound $\mathbf{3 a - 3 j}$ is depicted in Scheme 1.

\subsection{General procedure for the synthesis of 3,5- diarylisoxazoles $(\mathbf{4} \boldsymbol{a}-\mathbf{4 j})$}

A mixture of synthesized $\alpha, \beta$-unsaturated ketone $\mathbf{3 a} \mathbf{a} \mathbf{3 j}$ (1 mmol), hydroxylamine hydrochloride $(2.5 \mathrm{mmol})$ and sodium acetate $(2.5 \mathrm{mmol})$ in methanol was refluxed at $45^{\circ} \mathrm{C}$ for $4 \mathrm{~h}$. All the synthesized compounds were purified by column chromatography using silica gel (60-120 mesh) until a constant transition temperature was obtained to get the 3,5-disubstituted isoxazoles $\mathbf{4 a - 4 j}$ series as white puffy solids. The synthesis is depicted in Scheme 2.

\subsection{Characterization}

All the common reagents and solvents were used as purchased from commercial suppliers without any further purification. For some representative compounds, IR spectra in the spectral range of $400-4000 \mathrm{~cm}^{-1}$ were recorded using Perkin Elmer FTIR. ${ }^{1} \mathrm{H}$ NMR and ${ }^{13} \mathrm{C}$ NMR spectroscopy techniques were recorded using Agilent-NMR $400 \mathrm{MHz}$ using $\mathrm{CDCl}_{3}$ and the chemical shifts were recorded in ppm relative to TMS as an internal standard. Mass spectra were recorded in a mass spectrometer of Synapt G2 HDMS. The liquid crystalline properties, transition temperatures and melting temperatures were investigated by using optical polarizing microscope in conjunction with LTS 420 Lincam hot stage of Olympus BX51 model. The mesophase type was determined by comparison of the observed texture with the corresponding standards. ${ }^{19}$ Samples were<smiles>CCOc1ccc(C(C)=O)cc1</smiles>

(1)<smiles>[R]Oc1ccc(C=O)cc1OC</smiles>

(2)

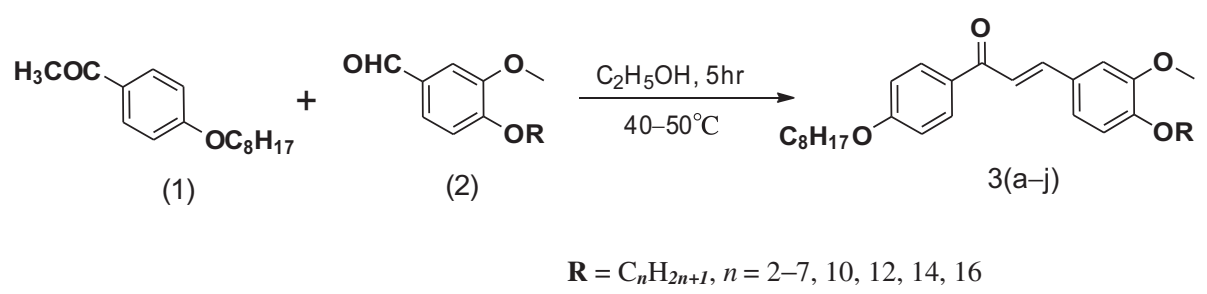

Scheme 1. Synthetic route for chalcones.

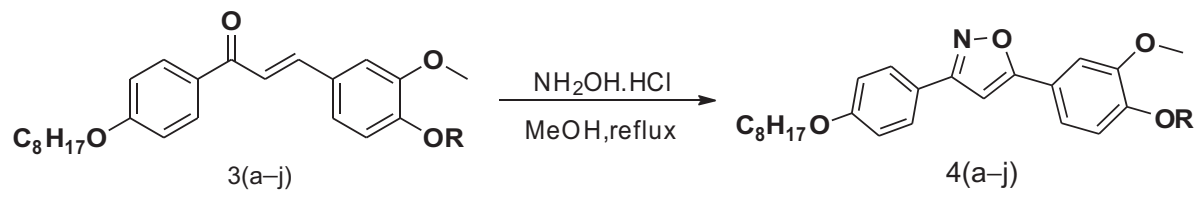

$$
\mathbf{R}=\mathrm{C}_{n} \mathrm{H}_{2 n+1}, n=2-7,10,12,14,16
$$

Scheme 2. Synthetic route to the isoxazoles.

3a: $\mathbf{R}=\mathbf{C}_{2} \mathbf{H}_{5}$

3b: $\mathbf{R}=\mathbf{C}_{3} \mathbf{H}_{7}$

3c: $\mathbf{R}=\mathrm{C}_{4} \mathrm{H}_{9}$

3d: $\mathbf{R}=\mathrm{C}_{5} \mathrm{H}_{11}$
Series (I) $\mathbf{3 a} \mathbf{a} \mathbf{3} \mathbf{j}$

3e: $\mathbf{R}=\mathrm{C}_{6} \mathrm{H}_{13}$

3f: $\mathbf{R}=\mathbf{C}_{7} \mathbf{H}_{15}$

3g: $\mathrm{R}=\mathrm{C}_{10} \mathrm{H}_{21}$

3h: $\mathbf{R}=\mathrm{C}_{12} \mathrm{H}_{25}$ 3i: $\mathbf{R}=\mathrm{C}_{\mathbf{1 4}} \mathrm{H}_{29}$

3j: $\mathrm{R}=\mathrm{C}_{\mathbf{1 6}} \mathrm{H}_{33}$
Series (II) $\mathbf{4 a} \mathbf{a}-\mathbf{4 j}$

4e: $\mathbf{R}=\mathrm{C}_{6} \mathrm{H}_{13}$

4f: $\mathrm{R}=\mathrm{C}_{7} \mathrm{H}_{15}$

4g: $\mathrm{R}=\mathrm{C}_{10} \mathrm{H}_{21}$

4h: $\mathrm{R}=\mathrm{C}_{12} \mathrm{H}_{25}$ 4i: $\mathrm{R}=\mathrm{C}_{14} \mathrm{H}_{29}$ 4j: $\mathrm{R}=\mathrm{C}_{16} \mathrm{H}_{33}$ 
Table 1. Elemental analysis for chalcone (series I) and isoxazoles (series II) derivatives.

\begin{tabular}{lccccc}
\hline S1. no & $\begin{array}{c}\text { Molecular } \\
\text { Formula }\end{array}$ & $\begin{array}{c}\text { Elements } \\
\mathrm{C}\end{array}$ & $\begin{array}{c}\% \text { Found } \\
\mathrm{H}\end{array}$ & $\begin{array}{c}\text { (\% Calculated }) \\
\mathrm{O}\end{array}$ & $\mathrm{N}$ \\
\hline $\mathbf{3 e}$ & $\mathrm{C}_{30} \mathrm{H}_{42} \mathrm{O}_{4}$ & $77.23(77.21)$ & $9.06(9.07)$ & $13.70(13.71)$ & - \\
$\mathbf{3 i}$ & $\mathrm{C}_{38} \mathrm{H}_{58} \mathrm{O}_{4}$ & $78.84(78.85)$ & $10.08(10.10)$ & $11.09(11.06)$ & - \\
$\mathbf{4 e}$ & $\mathrm{C}_{30} \mathrm{H}_{41} \mathrm{NO}_{4}$ & $75.10(75.12)$ & $8.63(8.62)$ & $13.35(13.34)$ & $2.94(2.92)$ \\
$\mathbf{4 h}$ & $\mathrm{C}_{36} \mathrm{H}_{53} \mathrm{NO}_{4}$ & $76.70(76.69)$ & $9.49(9.47)$ & $11.34(11.35)$ & $2.46(2.48)$ \\
\hline
\end{tabular}

prepared as thin films between a glass slide and a glass cover slip. X-Ray data were collected on a Bruker diffractometer. The UV-Visible absorption spectra for the mesomorphic compounds were recorded in chloroform using Shimadzu UV/PC 160-A spectrophotometer in the spectral range 200$800 \mathrm{~nm}$. Transition temperatures and associated enthalpies were determined by differential scanning calorimetry (DSC), using DSC Mettler TA 4000 at a scanning rate of $10^{\circ} \mathrm{C}$ $\min ^{-1}$ with controlled cooling accessory. The purity of the compounds was checked by TLC and further confirmed by elemental analysis (Table 1) using Perkin CHN analyzer; their results agreed favourably with the calculated values.

\subsection{Selected data}

2.5a 3-(4-butoxy-3-methoxyphenyl)-1-(4-(octyloxy)phenyl) prop-2-en-1-one $(3 \mathrm{c})$ : FT-IR $\left(\mathrm{cm}^{-1}\right)$ : 2917, 1738, 1646, 1365, 1311, 1261. ${ }^{1} \mathrm{H} \mathrm{NMR}\left(\mathrm{CDCl}_{3}, 100 \mathrm{MHz}\right) \delta: 0.89(\mathrm{t}$, $\left.-\mathrm{CH}_{3}, 3 \mathrm{H}\right), 1.04\left(\mathrm{t},-\mathrm{CH}_{2}, 3 \mathrm{H}\right), 1.29\left(\mathrm{~m},-\mathrm{CH}_{2}, 10 \mathrm{H}\right), 1.39$ $\left(\mathrm{m},-\mathrm{CH}_{2}, 2 \mathrm{H}\right), 1.88\left(\mathrm{~m},-\mathrm{CH}_{2}, 4 \mathrm{H}\right), 3.92\left(\mathrm{~s},-\mathrm{OCH}_{3}, 3 \mathrm{H}\right)$, $4.06\left(\mathrm{t}, 2 \times-\mathrm{OCH}_{2}, 4 \mathrm{H}\right), 6.87(\mathrm{~d}, \mathrm{ArH}, 1 \mathrm{H}), 6.95(\mathrm{~d}, \mathrm{ArH}$, 2H), 7.18 (d, ArH, 2H), 7.38 (d, $\alpha-\mathrm{H}$, chalcone), 7.73 (d, $\beta-\mathrm{H}$, chalcone), 8.01 (d, ArH, $2 \mathrm{H}) .{ }^{13} \mathrm{C} \mathrm{NMR}\left(\mathrm{CDCl}_{3}, 100 \mathrm{MHz}\right)$ $\delta: 10.32,10.42,14.00,22.37,22.41,25.96,29.10,29.18$, 29.29, 31.76, 56.03, 56.20, 68.17, 68.27, 70.47, 110.67, $110.80,112.49,114.20,114.25,119.68,119.82,122.82$, $122.96,127.90,130.62,130.72,131.11,144.01,144.16$, 149.52, 150.93, 162.90, 188.70. Yield: $88 \%$.

2.5b 3-(3-methoxy-4-(pentyloxy)phenyl)-1-(4-(octyloxy)phenyl) prop-2-en-1-one $(3 \mathrm{~d})$ : FT-IR $\left(\mathrm{cm}^{-1}\right)$ : 2914, 1656, 1365, 1320, 1261. ${ }^{1} \mathrm{H} \mathrm{NMR}\left(\mathrm{CDCl}_{3}, 100 \mathrm{MHz}\right) \delta: 0.89\left(\mathrm{t},-\mathrm{CH}_{3}\right.$, $6 \mathrm{H}), 1.37\left(\mathrm{~m},-\mathrm{CH}_{2}, 15 \mathrm{H}\right), 1.86\left(\mathrm{~m},-\mathrm{CH}_{2}, 4 \mathrm{H}\right), 3.92(\mathrm{~s}$, $\left.-\mathrm{OCH}_{3}, 3 \mathrm{H}\right), 4.03\left(\mathrm{t}, 2 \times-\mathrm{OCH}_{2}, 4 \mathrm{H}\right), 6.88$ (d, ArH, 1H), 6.97 (d, ArH, 2H), 7.18 (d, ArH, 2H), 7.35 (d, $\alpha-\mathrm{H}$, chalcone), 7.77 (d, $\beta$-H, chalcone), 8.04 (d, ArH, 2H). ${ }^{13} \mathrm{C}$ NMR $\left(\mathrm{CDCl}_{3}, 400 \mathrm{MHz}\right) \delta: 14.10,14.03,22.70,22.78,25.91$, 28.14, 29.32, 29.37, 29.60, 29.64, 31.19, 56.10, 68.70, 69.00, $111.12,114.70,118.2,122.30,126.70,129.60,130.60$, 130.71, 145.1, 149.83, 149.81, 165.22, 189.89. Yield: 82\%.

2.5c 3-(4-(heptyloxy)-3-methoxyphenyl)-1-(4-(octyloxy)phenyl) prop-2-en-1-one (3f): FT-IR $\left(\mathrm{cm}^{-1}\right)$ : 2914, 1650, 1360, 1318, 1268. ${ }^{1} \mathrm{H} \mathrm{NMR}\left(\mathrm{CDCl}_{3}, 100 \mathrm{MHz}\right) \delta: 0.88\left(\mathrm{t},-\mathrm{CH}_{3}\right.$, $6 \mathrm{H}), 1.34\left(\mathrm{~m},-\mathrm{CH}_{2}, 10 \mathrm{H}\right), 1.82\left(\mathrm{~m},-\mathrm{CH}_{2}, 4 \mathrm{H}\right), 3.92$
$\left(\mathrm{s},-\mathrm{OCH}_{3}, 3 \mathrm{H}\right), 4.04\left(\mathrm{t}, 2 \times-\mathrm{OCH}_{2}, 4 \mathrm{H}\right), 6.87$ (d, $\mathrm{ArH}$, 1H), 6.94 (d, ArH, 2H), 7.15 (d, ArH, 2H), 7.42 (d, $\alpha-\mathrm{H}$, chalcone), 7.73 (d, $\beta$-H, chalcone), 8.01 (d, ArH, 2H). ${ }^{13} \mathrm{C} \mathrm{NMR}\left(\mathrm{CDCl}_{3}, 400 \mathrm{MHz}\right) \delta: 14.1,22.72,22.80,25.92$, $25.97,29.30,29.40,29.62,29.72,31.82,31.96,56.12$, $65.70,68.76,69.02,112.12,114.85,114.95,121.34,122.12$, $122.30,126.60,129.50,130.50,145.60,149.82,149.88$, 165.20. Yield: $83 \%$.

2.5d 3-(4-(dodecyloxy)-3-methoxyphenyl)-1-(4-(octyloxy) phenyl)prop-2-en-1-one (3h): FT-IR $\left(\mathrm{cm}^{-1}\right)$ : 2914, 1656, 1368, 1339, 1257. ${ }^{1} \mathrm{H}$ NMR $\left(\mathrm{CDCl}_{3}, 100 \mathrm{MHz}\right) \delta: 0.85(\mathrm{t}$, $\left.-\mathrm{CH}_{3}, 6 \mathrm{H}\right), 1.27\left(\mathrm{~m},-\mathrm{CH}_{2}, 25 \mathrm{H}\right), 1.41\left(\mathrm{~m},-\mathrm{CH}_{2}, 4 \mathrm{H}\right)$, $1.85\left(\mathrm{~m},-\mathrm{CH}_{2}, 4 \mathrm{H}\right), 3.78\left(\mathrm{~s},-\mathrm{OCH}_{3}, 3 \mathrm{H}\right), 4.02(\mathrm{t}$, $\left.2 \times-\mathrm{OCH}_{2}, 4 \mathrm{H}\right), 6.85(\mathrm{~d}, \mathrm{ArH}, 1 \mathrm{H}), 6.95(\mathrm{~d}, \mathrm{ArH}, 2 \mathrm{H})$, 7.18 (d, ArH, 2H), 7.42 (d, $\alpha-\mathrm{H}$, chalcone), 7.75 (d, $\beta-\mathrm{H}$, chalcone), $8.05(\mathrm{~d}, \mathrm{ArH}, 2 \mathrm{H}) .{ }^{13} \mathrm{C} \mathrm{NMR}\left(\mathrm{CDCl}_{3}, 400 \mathrm{MHz}\right)$ $\delta: 14.00,14.12,22.62,22.65,25.91,25.97,29.03,29.11$, $29.18,29.51,29.52,29.60,31.76,31.89,56.04,56.21$, $68.12,68.27,68.43,69.21,110.64,112.45,114.27,122.87$, $123.03,127.88,130.76,144.05,149.53,150.97,162.92$. Yield: $80 \%$.

2.5e 5-(4-ethoxy-3-methoxyphenyl)-3-(4-(octyloxy)phenyl) isoxazole (4a): FT-IR $\left(\mathrm{cm}^{-1}\right)$ : 3454, 2917, 1613, 1583, 1304, 1251. ${ }^{1} \mathrm{H} \mathrm{NMR}\left(\mathrm{CDCl}_{3}, 400 \mathrm{MHz}\right) \delta: 0.88\left(\mathrm{t},-\mathrm{CH}_{3}\right.$, $3 \mathrm{H}), 1.29\left(\mathrm{~m},-\mathrm{CH}_{2}, 8 \mathrm{H}\right), 1.49\left(\mathrm{~m},-\mathrm{CH}_{2}, 2 \mathrm{H}\right), 3.86(\mathrm{~s}$, $\left.-\mathrm{OCH}_{3}, 3 \mathrm{H}\right), 3.98\left(\mathrm{t},-\mathrm{OCH}_{2}, 2 \mathrm{H}\right), 4.14\left(\mathrm{t},-\mathrm{OCH}_{2}, 2 \mathrm{H}\right)$, 6.64 (d, 1H), 6.94 (m, ArH, 3H), 7.45 (dd, J=8 Hz, ArH, 2H), $7.75(\mathrm{dd}, \mathrm{J}=8.8 \mathrm{~Hz}, \mathrm{ArH}, 2 \mathrm{H}) .{ }^{13} \mathrm{C} \mathrm{NMR}\left(\mathrm{CDCl}_{3}, 100 \mathrm{MHz}\right)$ $\delta: 14.20,14.70,22.70,25.90,29.23,29.56,31.87,56.12$, $64.89,68.72,98.36,108.50,111.12,114.93,114.98,119.28$, 119.87, 122.90, 128.20, 130. 20, 150.40, 150.67, 159.40, 162.04, 169.35. LCMS: $424.34[\mathrm{M}+\mathrm{H}]^{+}$; Yield: $78 \%$.

2.5f 5-(4-(hexyloxy)-3-methoxyphenyl)-3-(4-(octyloxy)phenyl) isoxazole (4e): FT-IR ( $\left.\mathrm{cm}^{-1}\right)$ : 2930, 2855, 1608, 1580, 1293, 1249. ${ }^{1} \mathrm{H} \mathrm{NMR}\left(\mathrm{CDCl}_{3}, 400 \mathrm{MHz}\right) \delta: 0.88\left(\mathrm{t},-\mathrm{CH}_{3}, 6 \mathrm{H}\right)$, $1.35\left(\mathrm{~m},-\mathrm{CH}_{2}, 12 \mathrm{H}\right), 1.44\left(\mathrm{~m},-\mathrm{CH}_{2}, 4 \mathrm{H}\right), 1.80\left(\mathrm{~m},-\mathrm{CH}_{2}\right.$, $4 \mathrm{H}), 3.94\left(\mathrm{~s},-\mathrm{OCH}_{3}, 3 \mathrm{H}\right), 4.01\left(\mathrm{t},-\mathrm{OCH}_{2}, 2 \mathrm{H}\right), 4.07(\mathrm{t}$, $\left.-\mathrm{OCH}_{2}, 2 \mathrm{H}\right), 6.65$ (d, 1H), 6.94 (m, ArH, 3H), 7.44 (dd, $\mathrm{J}=8 \mathrm{~Hz}, \mathrm{ArH}, 2 \mathrm{H}), 7.77$ (dd, J=8.8 Hz, ArH, 2H). ${ }^{13} \mathrm{C} \mathrm{NMR}$ $\left(\mathrm{CDCl}_{3}, 100 \mathrm{MHz}\right) \delta: 14.10,14.23,22.70,22.78,25.60$, $25.98,29.33,29.67,29.72,29.88,31.80,31.98,56.12$, $68.70,69.10,98.34,108.50,111.12,114.80,114.90,119.72$, 119.82, 122.91, 128.10, 128.23, 150.40, 150.62, 159.48. LCMS: $480.12[\mathrm{M}+\mathrm{H}]^{+}$; Yield: $75 \%$. 
$2.5 \mathrm{~g}$ 5-(4-(dodecyloxy)-3-methoxyphenyl)-3-(4-(octyloxy) phenyl)isoxazoles (4h): FT-IR $\left(\mathrm{cm}^{-1}\right)$ : 2921, 2851, 1614, 1584, 1373, 1257. ${ }^{1} \mathrm{H} \mathrm{NMR}\left(\mathrm{CDCl}_{3}, 400 \mathrm{MHz}\right) \delta: 0.86$ $\left(\mathrm{t},-\mathrm{CH}_{3}, 6 \mathrm{H}\right), 1.30\left(\mathrm{~m},-\mathrm{CH}_{2}, 26 \mathrm{H}\right), 1.43\left(\mathrm{~m},-\mathrm{CH}_{2}\right.$, $4 \mathrm{H}), 1.82\left(\mathrm{~m},-\mathrm{CH}_{2}, 4 \mathrm{H}\right), 3.93\left(\mathrm{~s},-\mathrm{OCH}_{3}, 3 \mathrm{H}\right), 4.03(\mathrm{tt}$, $\left.-2 \times-\mathrm{OCH}_{2}, 4 \mathrm{H}\right), 6.64(\mathrm{~d}, 1 \mathrm{H}), 6.91(\mathrm{~d}, \mathrm{ArH}, 1 \mathrm{H}), 6.95$ (dd, J=7.6 Hz, ArH, 2H), 7.34 (dd, J=8 Hz, ArH, 2H), $7.75(\mathrm{dd}, \mathrm{J}=8.8 \mathrm{~Hz}, \mathrm{ArH}, 2 \mathrm{H}){ }^{13} \mathrm{C} \mathrm{NMR}\left(\mathrm{CDCl}_{3}, 100 \mathrm{MHz}\right)$ $\delta: 14.01,14.10,22.63,22.62,25.93,25.93,29.08,29.15$, $29.19,29.32,29.57,29.61,29.78,31.78,31.89,56.01$, $56.21,67.96,68.12,68.18,69.05,69.08,98.30,108.50$, $111.10,114.90,114.20,119.20,122.90,128.10,150.40$, $150.60,159.40,162.00,169.30,160.70,162.61,170.13$, 170.23. LCMS: $564.52[\mathrm{M}+\mathrm{H}]^{+}$; Yield: $72 \%$.

2.5h 5-(4-(hexadecyloxy)-3-methoxyphenyl)-3-(4-(octyloxy) phenyl)isoxazole (4j): FT-IR $\left(\mathrm{cm}^{-1}\right)$ : 2917, 2850, 1614, 1509, 1373, 1253. ${ }^{1} \mathrm{H} \mathrm{NMR}\left(\mathrm{CDCl}_{3}, 400 \mathrm{MHz}\right) \delta: 0.86\left(\mathrm{t},-\mathrm{CH}_{3}\right.$, $6 \mathrm{H}), 1.34\left(\mathrm{~m},-\mathrm{CH}_{2}, 36 \mathrm{H}\right), 1.46\left(\mathrm{~m},-\mathrm{CH}_{2}, 2 \mathrm{H}\right), 1.77(\mathrm{~m}$, $\left.-\mathrm{CH}_{2}, 2 \mathrm{H}\right), 1.82\left(\mathrm{~m},-\mathrm{CH}_{2}, 2 \mathrm{H}\right), 3.96\left(\mathrm{~s},-\mathrm{OCH}_{3}, 3 \mathrm{H}\right)$, $4.01\left(\mathrm{t},-\mathrm{OCH}_{2}, 2 \mathrm{H}\right), 4.05\left(\mathrm{t},-\mathrm{OCH}_{2}, 2 \mathrm{H}\right), 6.64(\mathrm{~d}, 1 \mathrm{H})$, 6.94 (m, ArH, 3H), 7.35 (dd, J=8 Hz, ArH, 2H), 7.76 (dd, $\mathrm{J}=8.8 \mathrm{~Hz}, \mathrm{ArH}, 2 \mathrm{H}) .{ }^{13} \mathrm{C} \mathrm{NMR}\left(\mathrm{CDCl}_{3}, 100 \mathrm{MHz}\right) \delta: 14.01$, $14.12,22.70,22.78,25.90,25.78,29.14,29.32,29.57$, 29.60, 29.70, 29.82, 29.84, 29.86, 29.88, 29.90, 29.95, 29.97, 31.12 , 3190, 29.84, 29.86, 29.88, 29.90, 29.95, 29.97, 31.12, $31.90,31.93,56.01,68.72,69.80,98.12,108.5,111.12$, $114.78,119.20,119.67,122.97,150.30,130.70$. 162.00, 169.10, 170.14. LCMS: $620.24[\mathrm{M}+\mathrm{H}]^{+}$; Yield: $68 \%$.

\section{Results and Discussion}

\subsection{Thermal behaviour}

In an effort to understand the molecular structure-liquid crystal property relationship, the chain length in both the intermediate chalcone compounds and in final isoxazole compounds, one terminal alkoxy tail $\left(\mathrm{C}_{1}\right.$ to $\mathrm{C}_{7}$, $\mathrm{C}_{10}, \mathrm{C}_{12}, \mathrm{C}_{14}$ and $\mathrm{C}_{16}$ ) has been varied while keeping

Table 2. Transition temperatures of chalcones (series I) in ${ }^{\circ} \mathrm{C}$.

\begin{tabular}{lcccr}
\hline Sl. No & $\mathrm{R}=\mathrm{C}_{n} \mathrm{H}_{2 n+1}$ & Smectic & Nematic & Isotropic \\
\hline 3a & 2 & - & - & 99.1 \\
3b & 3 & - & - & 103.5 \\
3c & 4 & 68.9 & - & 88.8 \\
3d & 5 & 70.0 & - & 90.0 \\
3e & 6 & 73.0 & - & 89.0 \\
3f & 7 & 78.0 & - & 88.4 \\
3g & 10 & 58.9 & - & 76.9 \\
3h & 12 & 73.0 & - & 93.7 \\
3i & 14 & 79.7 & - & 93.5 \\
3j & 16 & 76.2 & - & 93.4 \\
\hline
\end{tabular}

Table 3. Transition temperatures of isoxazoles (series II) in ${ }^{\circ} \mathrm{C}$.

\begin{tabular}{lcccc}
\hline Sl. No. & $\mathrm{R}=\mathrm{C}_{n} \mathrm{H}_{2 n+1}$ & Smectic & Nematic & Isotropic \\
\hline $\mathbf{4 a}$ & 2 & - & - & 127.5 \\
$\mathbf{4 b}$ & 3 & - & - & 113.0 \\
$\mathbf{4 c}$ & 4 & 73.4 & - & 92.4 \\
$\mathbf{4 d}$ & 5 & - & 83.0 & 88.0 \\
$\mathbf{4 e}$ & 6 & 71.2 & - & 80.0 \\
$\mathbf{4 f}$ & 7 & - & 76.5 & 87.8 \\
$\mathbf{4 g}$ & 10 & 70.2 & 78.7 & 85.2 \\
$\mathbf{4 h}$ & 12 & 44.4 & 56.4 & 89.0 \\
$\mathbf{4 i}$ & 14 & - & 66.5 & 82.2 \\
$\mathbf{4 j}$ & 16 & - & 68.3 & 85.6 \\
\hline
\end{tabular}

the other terminal fixed by $\mathrm{C}_{8}$. The transition temperature and the phase sequence of the synthesized compounds in this investigation are presented in Tables 2 and 3. The mesomorphic behaviour of all the synthesized compounds was evaluated mainly by optical studies. However, for some representative compounds, the phase transition temperatures have been confirmed by DSC studies. Both the series exhibit nematic and/or smectic phases. The molecular structures of the two series of compounds differ at the core, where the series I has $\alpha, \beta$-unsaturated ketone while series II has a rigid isoxazole ring at the core. Therefore, both the set of series exhibit different mesomorphic properties even though lateral substitutions are same. The characteristic optical texture images procured from polarizing optical microscopy (POM) are represented in Figure 1. Figure 1(a) shows the photomicrograph of the $\mathrm{Sm}$ phase at $58^{\circ} \mathrm{C}$ for the decyl derivative $\mathbf{3 g}$ of series-I; Figure 1(b) shows the texture of $\mathrm{N}$ phase at $56.4^{\circ} \mathrm{C}$ for the dodecyl derivative $4 \mathbf{h}$ of series-II; Figure 1(c) shows the texture of $\mathrm{N}$ phase at $83.0^{\circ} \mathrm{C}$ for the pentyl derivative 4d of series-II; and, Figure 1(d) shows the texture of $\mathrm{N}$ phase at $68.3^{\circ} \mathrm{C}$ for the hexadecyl derivative $\mathbf{4 j}$ of series-II.

The resultant series exhibits liquid crystalline properties from the butyl to the hexadecyl homologous, while the ethyl and methyl homologues in both the series are non- mesogenic. Non-mesomorphic behaviour of the ethyl and methyl homologue derivatives is attributed to their high crystallizing tendency due to their relatively short alkoxy terminal chains. Hence, the corresponding homologous molecules are unable to resist exposed thermal vibrations, which result in the sudden breaking of the crystal structure and convert the substance sharply into the isotropic liquid state from the solid state, without exhibition of a liquid crystalline mesophase. Hence, they melt sharply without showing any liquid crystal property. 


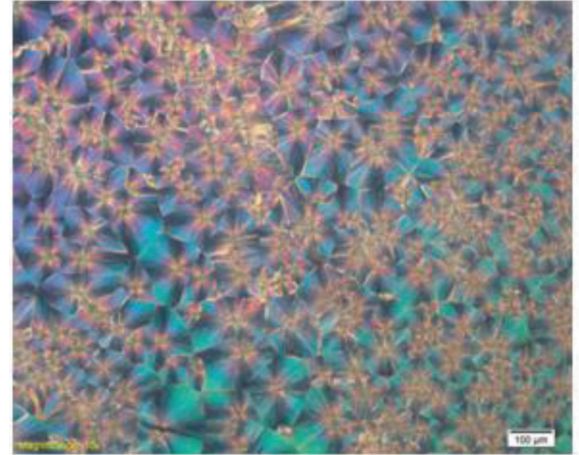

(a)

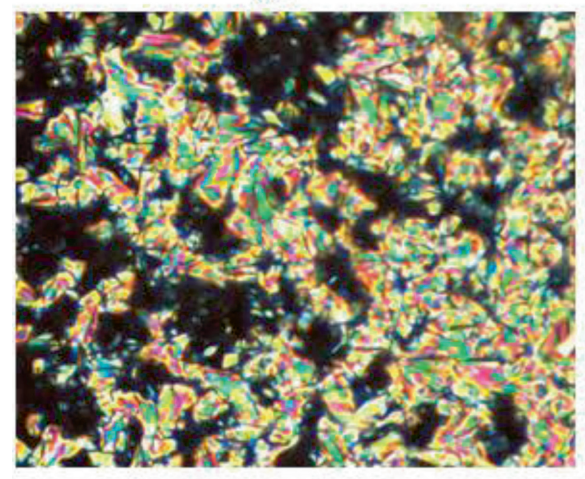

(c)

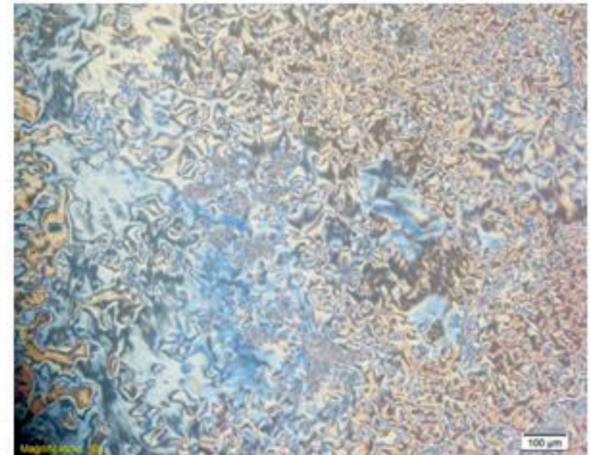

(b)

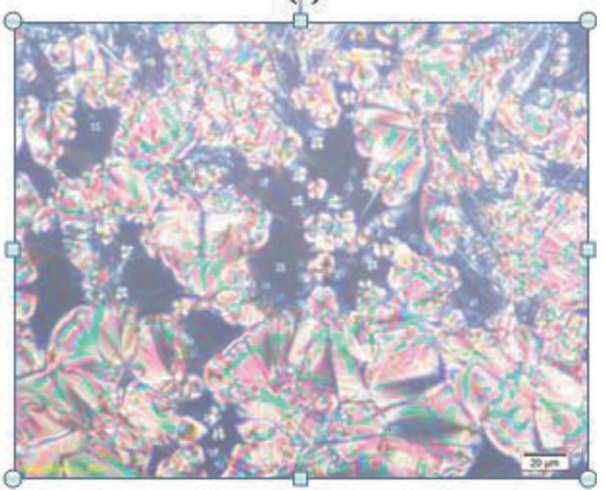

(d)

Figure 1. Characteristic optical textures (a) Sm phase observed for $3 \mathrm{~g}$ at $58.9^{\circ} \mathrm{C}$; (b) $\mathrm{N}$ phase observed for $4 \mathbf{h}$ at $56.4^{\circ} \mathrm{C}$; (c) $\mathrm{N}$ phase observed for $4 \mathbf{d}$ at $83^{\circ} \mathrm{C}$; and (d) $\mathrm{N}$ phase observed for $\mathbf{4 j}$ at $68.3^{\circ} \mathrm{C}$.

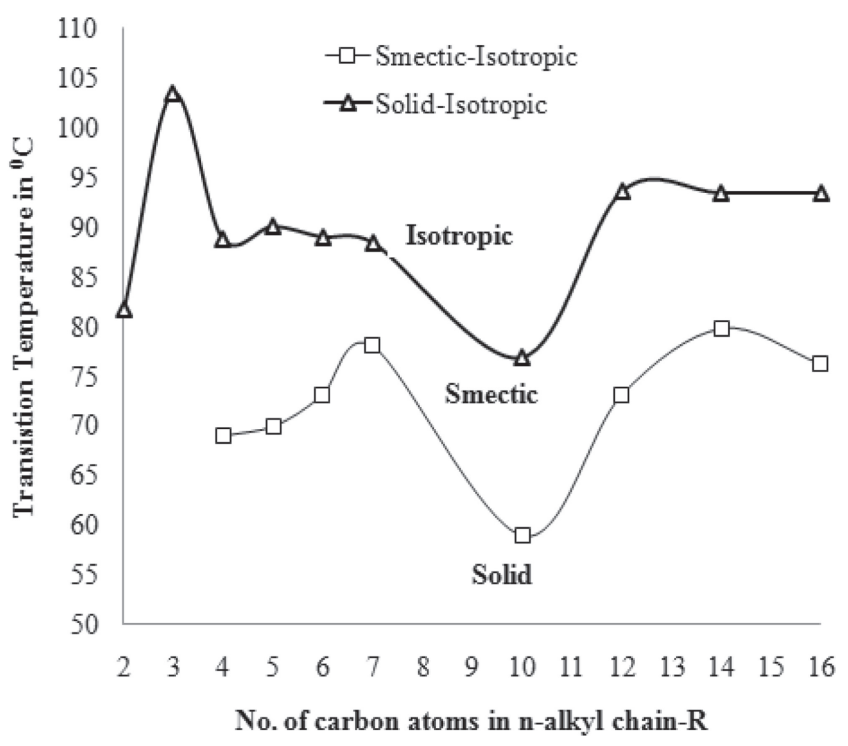

Figure 2. Plot of transition temperature against the number of carbon atoms in the n-alkoxy chains for series $\mathbf{I}$.

A plot of the transition temperature versus the number of carbon atoms present in the n-alkyl terminal chain consists of three transition curves, solid isotropic/ mesomorphic transition curve, smectic-nematic curve and nematic-isotropic curve for both the chalcone and isoxazole series, as shown in Figures 2 and 3. The solid isotropic or mesomorphic transition curve rises

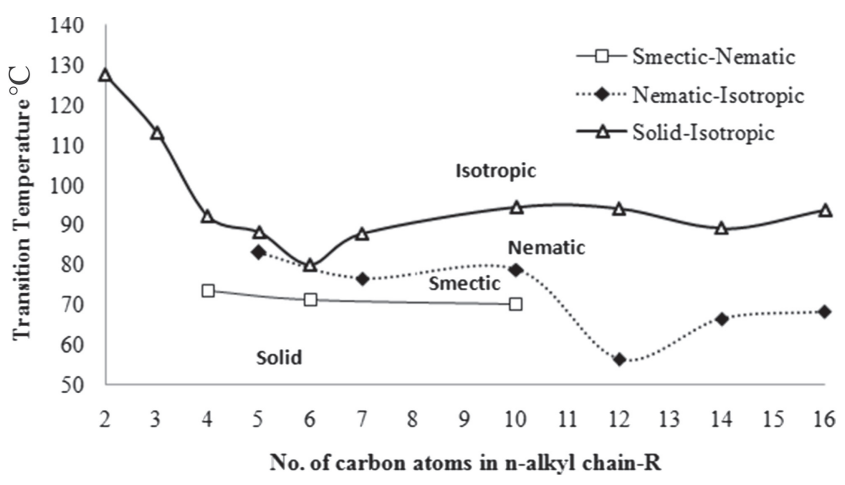

Figure 3. Plot of transition temperature against the number of carbon atoms in the n-alkoxy chains for series II.

and falls in the series, in a zigzag manner, and it is also observed that the isotropic curve descended gradually in the series II, thus exhibiting enhanced liquid crystalline nature. The present investigation showed predominantly smectogenic and partly nematic with a middle ordered melting type. Liquid crystalline transitions vary in both the series with different magnitudes of phase lengths, including smectic and nematic phase lengths.

All the mesogenic members of the series are enantiotropic in nature. The exhibition of mesogenic properties from the butyl to the hexadecyl homologues 
is attributed to the suitable magnitudes of anisotropic intermolecular forces of attraction caused by the favourable molecular polarity and polarizability, aromaticity, electronic-electronic interactions, length-tobreadth ratio and the ratio of the polarity to polarizability as a consequence of the resultant molecular rigidity and flexibility. ${ }^{20}$

Variations in the mesomorphic properties in both the series are attributed to the variation in the central group or the terminal alkoxy groups, keeping the other one fixed. All the compounds in the series $\mathbf{I}$, except ethyl and methyl homologues, exhibited only smectogenic character. As the chain length increases, the liquid crystalline property was also enhanced. In general, the $\alpha, \beta$-unsaturated ketones significantly increase the molecular width, making the parallel alignment of the molecules required to achieve mesomorphism. While the series II exhibited both the smectic and nematic phase in some compounds, but predominantly nematogenic which can be attributed due to the presence of rigid isoxazole core at the centre owing to their ability to impart lateral and/or longitudinal dipoles combined with changes in the molecular shape as most of the hetroatoms ( $\mathrm{N}, \mathrm{O}$ and $\mathrm{S}$ ) are more polarizable than carbon and by increased conjugation through the molecule. This favours the molecular planarity and anisotropy of electronic polarizability whichconsequently promote liquid crystal behaviour. Further, the presence of heterocyclic moiety increased the liquid crystalline nature and dramatically decreased the melting point of the compounds by extended conjugation through the molecule in mesophase formation. The Representative UV-Vis spectra of isoxazole derivatives $4 \mathbf{e}, \mathbf{4 f}, \mathbf{4 h}$ and $4 \mathbf{i}$ in chloroform $\left(5 \times 10^{-6} \mathbf{M}\right)$ are included in Figure S22 in the Supplementary Information. Isoxazoles derivatives exhibited absorption maximum at $320 \mathrm{~nm}$. For the whole series, there is not much change in the absorption maximum due to the variation of the terminal length of alkyl chains at similar concentrations. The absorption at $293 \mathrm{~nm}$ and $287 \mathrm{~nm}$ are attributed to $\pi-\pi^{*}$ and at $320 \mathrm{~nm}$ is due to $n-\pi^{*}$ transitions involving phenyl-isoxazole segment.

\section{Conclusions}

In conclusion, simple and convenient procedures were employed to obtain 20 compounds in moderate to good yields to study their mesomorphic behaviour by POM and DSC. To understand the structure-property relationship, alkoxy tails have been varied while keeping the other alkyl terminal fixed. Molecules with trans $\alpha$, $\beta$-unsaturated ketones and isoxazole ring at the central core were studied. Our investigations revealed that both the series, except for methyl and ethyl homologues, exhibited stable mesomorphic state. Series I exhibited predominantly smectic phase while in the series II, middle and higher homologues exhibited smectic and nematic phase. Overall, variations in the mesomorphic properties of the synthesized series are attributed to varying features in central group, linking group, molecular shape and rigidity.

\section{Supplementary Information (SI)}

All additional information pertaining to the characterization of the synthesized compounds using Mass, ${ }^{1} \mathrm{H}$ and ${ }^{13} \mathrm{C}$ NMR spectra, DSC, POM images and UV-Vis spectra are given in the supporting information available at www.ias.ac. in/chemsci.

\section{Acknowledgements}

The authors would like to acknowledge Department of Science and Technology, Govt. of India, for INSPIRE fellowship (DST/INSPIRE Fellowship/ 2012/328) for the financial support. Authors would also like to acknowledge University of Mysore, for necessary facilities and instrumentation.

\section{References}

1. Katto T, Mizoshita N and Kishimoto K 2006 Functional liquid-crystalline Assemblies: Self-Organised Soft Materials Angew. Chem. Int. Ed. 4538

2. Marcos M, Omenat A, Serrano J L and Ezcurra A 1992 A Ferroelectric liquid crystal dimer: Synthesis and properties Adv. Mater. 4285

3. Gray G W, Harrison K J and Nash J A 1973 New family of nematic liquid crystals for displays Electron. Lett. 9 130

4. Hird M, Toyne K J, Gray G W, Day S E and Mc Donnell D G 1993 The synthesis and high optical birefringence of nematogens incorporating 2,6-disubstituted naphthalenes and terminal cyanosubstituent Liq. Cryst. 15123

5. (a) Gray G W and Windsor P A 1974 In Liquid Crystals and Plastic Crystals 1 (Chichester: Ellis Horwood) Ch. 4; (b) Gray G W 1962 In Molecular Structure and the Properties of Liquid Crystal (London/New York: Academic Press)

6. Vieira A A, Bryk F R, Conte G, Bortoluzzi A J and Gallardo H 2009 1,3-Dipolar cycloaddition reaction applied to synthesis of new unsymmetric liquid crystal compounds-based isoxazole Tetrahedron Lett. 50 905

7. Tanaka M, Haino T, Ideta K, Kubo K, Mori A and Fukazawa Y 2007 Combinatorial synthesis of isoxazole library and their liquid crystalline properties Tetrahedron 63652 
8. Gallardo H, Zucco C and Da Silva L 1993 Synthesis and Characterization of a new Series of Liquid Crystal Compounds Derived from Isoxazoles Mol. Cryst. Liq. Cryst. 373181

9. Haino $\mathrm{T}$, Tanaka M, Ideta $\mathrm{K}$, Kubo K, Mori A and Fukazawa Y 2004 Solid-phase synthesis of liquid crystalline isoxazole library Tetrahedron Lett. $\mathbf{4 5}$ 2277

10. Kovganko V N and Kovaganko N N 2006 Synthesis of New Liquid-crystalline Compounds from the 3-Aryl-5-alkylpyrazole Series Russ. J. Org. Chem. 42 696

11. Gallardo H, Santos D M P de O, Caramori G F, Molin F and Bechtold I H 2013 Synthetic pathway for a new series of liquid crystal 2,6-disubstituted imidazo [2,1b] $[1,3,4]$ thiadiazole Liq. Cryst. 40570

12. Roddecha S and Anthamatten M 2010 Synthesis and thermotropic behaviour of imidazole-terminated liquid crystals Liq. Cryst. 37389

13. Selvarasu C and Kannan P 2015 Bent Shaped 1,3,4oxadiazole/Thiadiazole heterocyclic rings containing Liquid Crystals J. Chem. Sci. 1271831
14. Yhya R K, Rai K M L and Musad E A 2013 One-pot synthesis of new series 3,4,5-trisubstituteddihydroisoxazoline derivatives via 1,3-dipolar cycloaddition of nitrile oxides with chalcones J. Chem. Sci. 125799

15. Zelenin K N 2009 Recent Advances in the Reactions of Hydrazines and Hydroxylamines with $(\alpha, \beta$ Unsaturated and $\beta$-Dicarbonyl compounds) Org. Prep. Proced. Int. 27519

16. Iglesias R, Serrano J L and Sierra T 2010 FLCs with a five-membered ring in the mesogenic core Liq. Cryst. 2237

17. Chaudhari R P, Chauhan M L and Doshi A V 2013 Synthesis and Mesogenic Behaviour of Novel Liquid Crystals With a $-\mathrm{CH}=\mathrm{CH}-\mathrm{CO}-$ Central Bridge Mol. Cryst. Liq. Cryst. $\mathbf{5 7 5} 88$

18. Furniss B S, Hannaford A J, Smith P W G and Tatchell A R 1978 In Vogel's Text Book of Practical Organic Chemistry $4^{\text {th }}$ edition (London, UK: Longmann)

19. Dierking I 2003 In The Texture of Liquid Crystals (Berlin: Wiley-VCH Verlag)

20. Singh S 2002 In Liquid Crystals Fundamentals (Singapore: World Scientific) 